\title{
EFFICIENCY OF OIL-PRODUCTION: THE ROLE OF INSTITUTIONAL FACTORS
}

\author{
OLENA ChYGRYN ${ }^{\circledR}$ OleksII LYULYOV \\ Tetyana Pimonenko SaAd MlaAbdal
}

\begin{abstract}
A B S T R A C T
The article aims to provide a theoretical basis for the assessment of the institutional impact on oil production. The availability of fuel is the key driver of the functioning national economy, which determines the strategic and tactical landmarks of socioeconomic development and vectors of the country's foreign economic course. Such tendencies are represented in the results of the provided correlation analysis of the fluctuation between oil-production volumes and greenhouse gas emissions, the use of alternative energy sources, the number of patents for oil production, and unemployment. The provided bibliometric analysis, which was made using VOSviewer, has shown the content of interconnections between the categories of oil production and institutional determinants. The authors hypothesised that changes in the institutional environment and their interconnectedness formed a chain "oil production and oil rents $\rightarrow$ the level of corruption $\rightarrow$ the efficiency of public governance". The hypothesis was confirmed by constructing a system of dynamic models and using the Generalised Method of Moments. The calculations confirmed that oil rents were associated with corruption and were a direct threat to the stability of public institutions. An increasing level of corruption was associated with an increase in the level of rent payments and occurred only when the quality of democratic institutions was below the threshold level. The current level of efficiency in public administration did not have a significant impact on national oil production. Of all indicators, only the level of political stability had a statistically significant impact on oil production. The identified interconnections provide the basis for creating an efficient state policy aimed at effectively functioning state institutions, which promote the development of the oil industry, and the reduction of the country's energy dependence as well as strengthen the resilience of the national economy.
\end{abstract}

KEY WORDS

oil production, corruption, oil rent, corruption, government

10.2478/emj-2020-0030

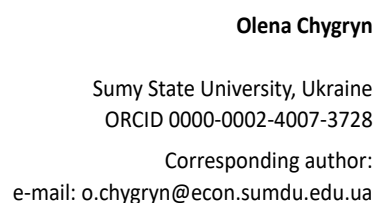

Oleksii Lyulyov

Sumy State University, Ukraine ORCID 0000-0002-4865-7306

Tetyana Pimonenko

Sumy State University, Ukraine ORCID 0000-0001-6442-3684

Saad Mlaabdal

Sumy State University, Ukraine

\section{INTRODUCTION}

The level of development of the national economy determines the strategic and tactical guidelines for the socio-economic policy of countries, regions, and global organisations. In turn, the economic, social and environmental development depends on many factors, causes and prerequisites.

One of the most critical factors in determining the content of policies is the availability of raw materials and fuel. The contemporary technologically

Chygryn, O., Lyulyov, O., Pimonenko, T., \& Mlaabdal, S. (2020). Efficiency of oil-production: the role of institutional factors. Engineering Management in Production and Services, 12(4), 92-104. doi: 10.2478/emj-2020-0030 
advanced society consumes enormous amounts of energy, which, in turn, raised considerable interest in energy sources. In the structure of global fuel consumption, oil occupies the first place with about $30 \%$, and it is projected to maintain this figure for many years to come (Yevdokimov et al., 2018; Naser, 2019; Miśkiewicz, 2018). Gas and coal lack many useful properties of oil, such as ease of transportation or high heat of combustion (Miśkiewicz, 2020). Thus, having a significant place in the structure of the fuel and energy mix, oil deposits and the scale of oil production are significant determinants, which largely define the content of processes in the economy of individual countries, regions and around the world (Dźwigoł, 2018).

It should be noted that theoretical and applied aspects related to the functioning of the oil industry are widely represented in scientific publications devoted to the study of the main determinants of the industry, the impact of political factors and international oil cartels on the industry, and the analysis of conflicts in oil production. Also, scientists (Kuzior, 2019; Dzwigol, 2020; Czyżewski, 2019) investigated the efficient development of state institutions, which could be realised based on several principles, i.e., the focus on long-term goals of development; equal access to the subsoil; transparency; standardisation of information about resources; stakeholder inclusive- ness; systematic approach and complexity; ecological and socio-economic efficiency; consecution; accountability; prevention; adaptability and flexibility of public administration; and the focus on innovation.

The efficiency of the oil production industry is a category connected with the economic, political, institutional, ecologic and social components. However, the influence of institutional factors on the efficiency of the oil industry is still insufficiently studied. So, Fig. 1 shows the results of a correlation analysis into the fluctuation of oil production volumes (for EU countries and the world) and greenhouse gas emissions, the use of alternative energy sources, the number of patents for oil production, and unemployment. The relevant trends are determined by distinguishing the cyclic time-series component by the Godrick-Prescott filter (1), which leads to the conclusion regarding a close correlation between oil extraction and socio-economic parameters of countries.

$$
\min _{\tau_{t}} \sum_{t=1}^{\mathrm{T}}\left(\left(\mathrm{y}_{\mathrm{t}}-\tau_{\mathrm{t}}\right)^{2}+\lambda\left(\left(\tau_{\mathrm{t}+1}-\tau_{\mathrm{t}}\right)-\left(\tau_{\mathrm{t}}-\tau_{\mathrm{t}-1}\right)\right)^{2}\right)
$$

$\tau_{t}$ - trend component, which is determined from the actual data series $y_{t} ; y_{t}-$ actual data of the value of the $\mathrm{j}$-th element of socio-ecological and economic parameters and volumes of oil production; $\mathrm{T}=1 \ldots \mathrm{t}$ — the study period.

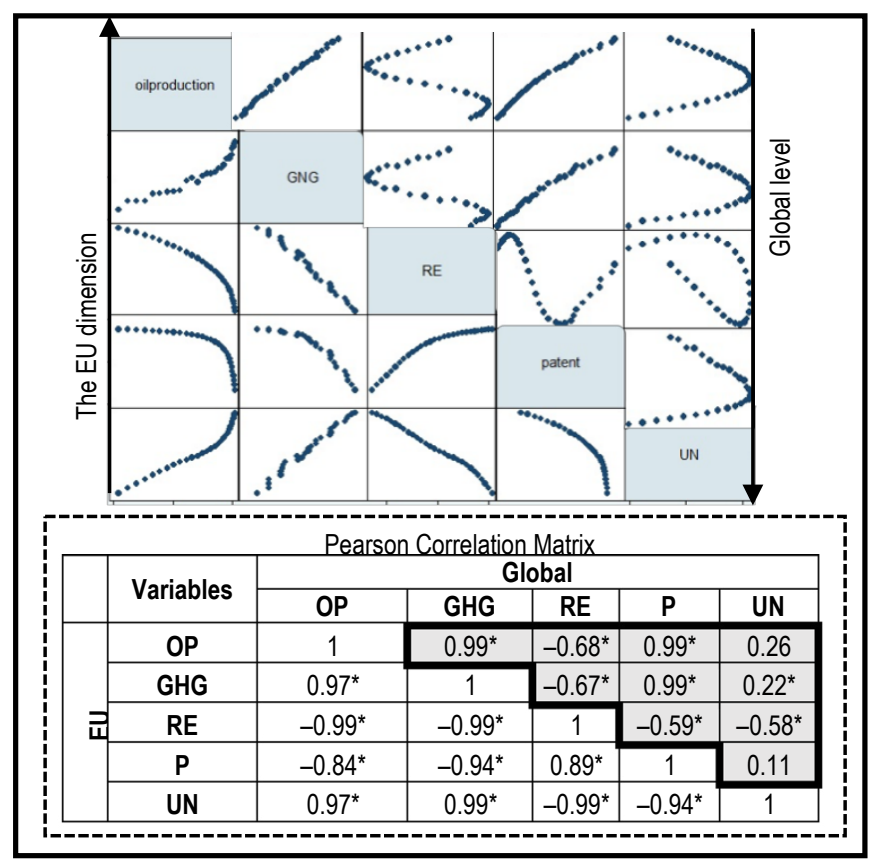

Fig. 1. Results of the correlation analysis into the fluctuation between oil production volumes (for EU countries and the world), greenhouse gas emissions, the use of alternative energy sources, the number of patents for oil production and unemployment

Note: OP - volumes of oil production; GHG - greenhouse gas emissions; RE - the share of alternative energy sources; P - number of patents; UN - unemployment rate; * - statistical significance at the level of $1 \%$ 
For the EU countries and the global dimension, the correlation is close: $97 \%$ and $99 \%$ between oil production and greenhouse gas emissions; $99 \%$ and $68 \%$ between the oil extraction and specific use of alternative energy sources; $84 \%$ and $99 \%$ between the oil production and the number of patents for oil production; and $97 \%$ and $26 \%$ between the oil production and unemployment. Thus, the development of the oil industry and the decrease in the greenhouse gas emissions could be realised through a greater focus on renewable energy and the implementation of sustainable development principals in the oil industry (Boiko, 2019). In this case, researchers (Cebula et al., 2018; Bhowmik, 2019; Hasan, 2019; $\mathrm{He}, 2019)$ proved a positive impact of green investments on declining GHG emissions and increasing share of renewable energy. Several researchers (Vasilieva et al., 2017; Bilan et al., 2018a) also confirmed that government transparency and social policy had a significant impact on the sustainable development of other sectors and investment attractiveness. Besides, a number of studies (Vasylyeva et al., 2014; Lyulyov et al., 2019; Sokolenko et al., 2017; Mentel et al., 2018; Kwilinski, 2019) proved that the modernisation of technologies in the oil industry and the development of green technologies led to a decline in GHG emissions and an increase in GDP.

Meanwhile, the results of studies (Abaas et al., 2018; Bilan et al., 2019b; Pimonenko et al., 2018; Wale-Awe \& Sulaiman, 2020) indicate that, in addition to traditional factors, several institutional factors influence the efficiency of the oil industry. A significant impact is made by an intense shadow in the industry, non-transparency of regulatory mechanisms for issuing permits and licenses for production, and corruption in the allocation of quotas for oil production. The goal of the article is to provide a theoretical basis for the assessment of the institutional impact on the oil-production industry.

\section{LITERATURE REVIEW}

The interdependence between the macroeconomic stability and the quality of the institutional environment has been proved by several research efforts (Lyeonov et al., 2019; Bilan et al., 2019a). The main indicators used to measure the quality of public administration have been selected as indicators of the institutional environment. In their paper, Hooke and Yongruck (2019) noted that the effectiveness of state governance affected the competitiveness of countries.
Meanwhile, several authors (Chygryn et al., 2018; Kozmenko et al., 2011; Brychko et al., 2019; Grenäãkovã, et al., 2019; Marcel, 2019; Augbaka et al., 2019; Pleines et al., 2016) confirmed that the financial stability and an investment climate had an impact on the national stability. Other authors (Bilan et al., 2019a; Vasilyeva, 2019) confirmed the effect of the country's brand and the stability on its competitiveness.

A statistically significant correlation has been found (Sadaf at al., 2018) between the levels of corruption and the effectiveness of governance in the country. A linear regression model has been used to confirm the hypothesis of the study. It has also been found that increased controls on corruption and increased political stability led to a reduction in the number of fraud cases in all sectors of the national economy. Also, the hypothesis regarding a relationship between the effectiveness of governance in the country and inclusive development has been empirically confirmed (Chou, 2018) as well as the growth of corruption under conditions of the shadow economy (Levchenko et al., 2018).

Using the results of panel data analysis, researchers (Awan et al., 2018) concluded that the efficiency of governance and political stability have a positive and statistically significant impact on the economic growth of the country. In addition, corruption has a negative impact on the economic growth of the country, and the effectiveness of governance has the most significant impact on the dynamics of the GDP growth. The Fixed Effects Method and the Hausman test were used to confirm the hypothesis empirically.

The hypothesis of a causal relationship between levels of economic development, corruption, and political instability, as exemplified by West African countries, was empirically confirmed (Nurudeen et al., 2015) with the help of the Granger test and the method of error correction. The results indicated a positive unidirectional dependence of political instability on economic development in the short term and a positive unidirectional dependence of political instability on economic development as well as long-term corruption in West African countries. A statistically significant impact of the level of corruption and the effectiveness of government on the country's competitiveness has been highlighted in the study by Cheng et al. (2017). Huque (2019) confirmed the hypothesis that freedom, voice and accountability affect the country's development.

The impact of corruption in the oil and gas sector on the country's economic growth rate has been addressed by Donwa et al. (2015). Pleines et al. (2016) 
examined the example of Caspian oil and gas and concluded that the internationalisation of corruption negatively impacted the development of the oil and gas sector. In the Caspian countries, the oil and gas industry was found to be a key element of their competitiveness; thus, it was crucial to increase the efficiency and quality of government regulation in order to reduce corruption.

To understand the content of interconnections between the categories of oil production and institutional determinants, a bibliometric analysis was performed to determine the spread of the categories. Articles indexed in the Scopus base were selected for analysis.

Scopus analysis tools were used to review more than 15000 papers announced in 1990-2018 (Fig. 2).

The Scopus screening tools showed 1995 as the year for the start of the growth in the number of articles regarding the influence made by the institutional environment on the oil industry. 2018 already saw about 15000 articles, which is an increase of approx. 15 times compared to 1995 (Fig. 2). The relevance of the problems and scientific interest connected with inequalities in the oil extraction countries is continuously growing.

The main subject areas (Fig. 3) related to the marketing strategies are energy, earth and planet science, engineering, chemical engineering, environmental science, business, management and accounting, chemistry, social science etc.

The citation analysis, provided by VOSviewer (Halicka, 2017; Gudanowska, 2017; Siderska \& Jadaa, 2018; Winkowska et al., 2019) determined the most authoritative researchers as well as the nine clusters of research teams that had the most significant influence on the theory which describes the interconnections between oil production tendencies and the institutional environment in national economies (Fig. 4). The cluster connected with corruption includes such categories as governance, property rights, economic

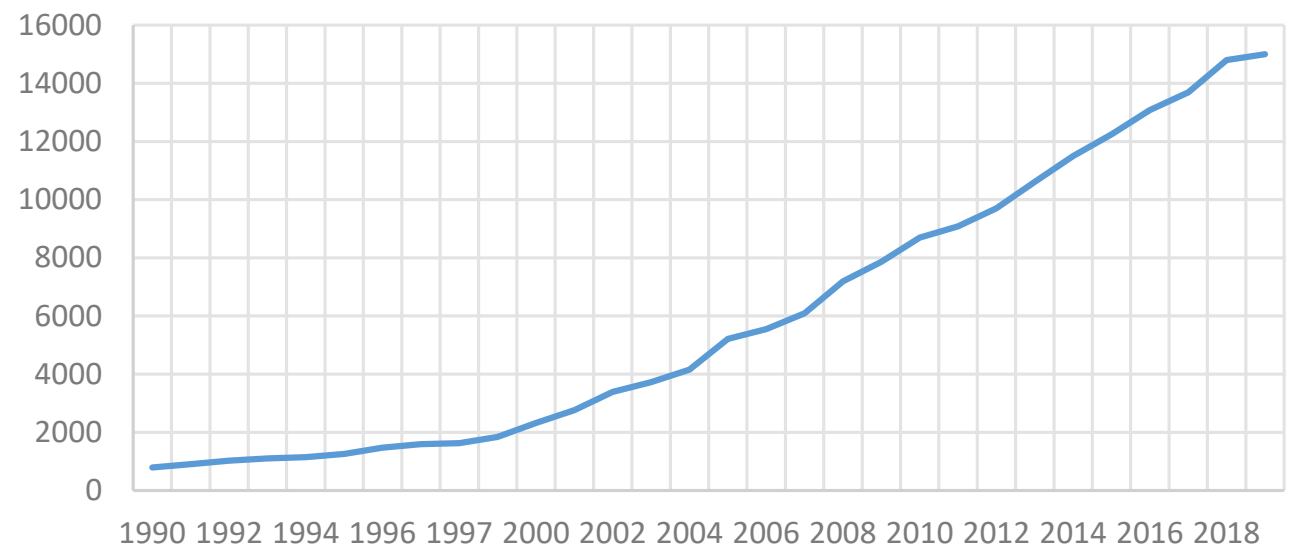

Fig. 2. Results of the trend analysis in publications related to oil production and institutional environment Sources: elaborated by the authors based on Scopus.

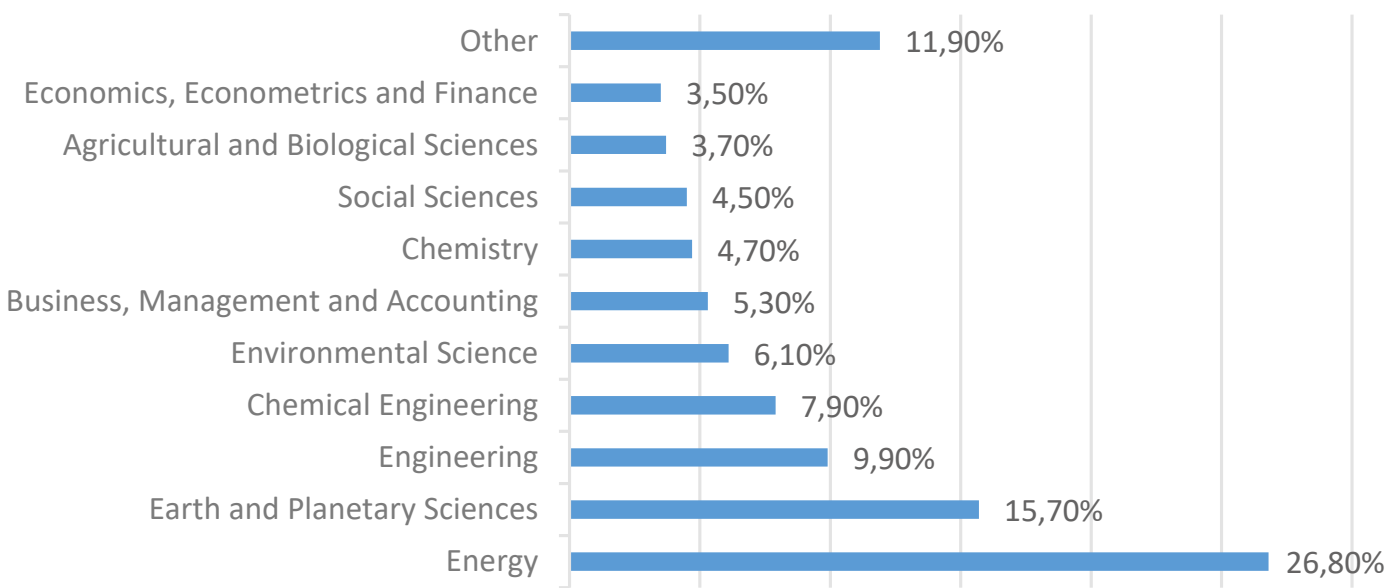

Fig. 3. Subject areas in Scopus dealing with the oil industry and institutional environment Source: elaborated by the authors based on Scopus. 


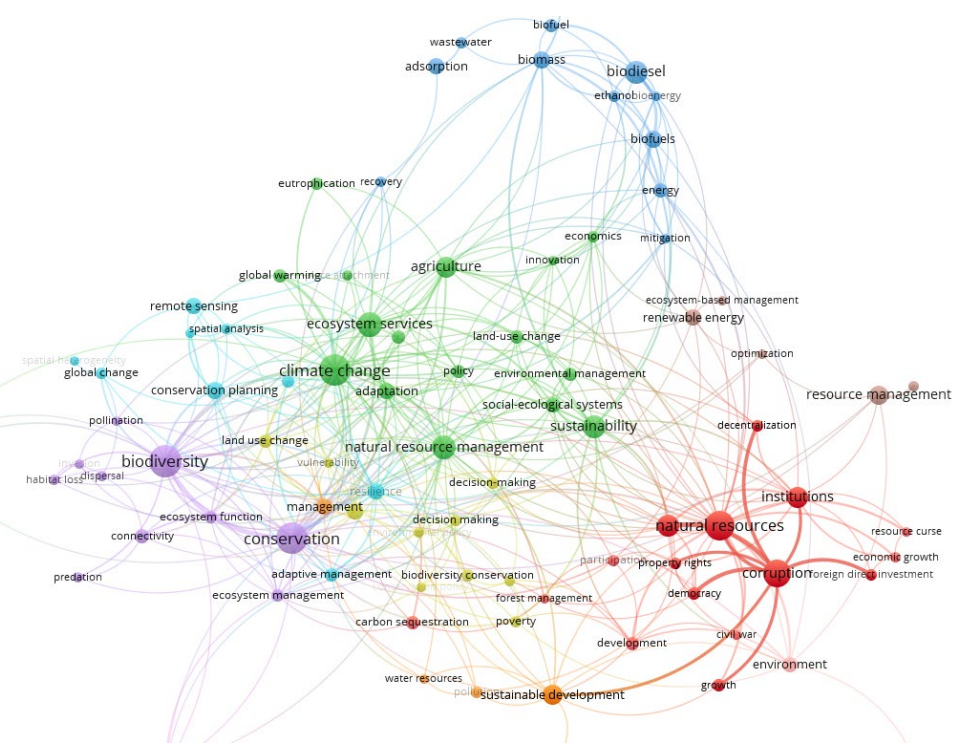

Fig. 4. Results of bibliometric analysis of the structural and functional environment for categories of the oil industry and institutional environment

Source: elaborated by the authors based on Scopus.

growth etc. Another big cluster relates to categories of conservation, biodiversity, and climate change. That explains the influence of the oil industry on the natural environment.

Considering the above-mentioned results of the analysis, this paper hypothesised that changes in the institutional environment and their interconnectedness occurred in the form of a chain, namely, "oil production and oil rents $\rightarrow$ the level of corruption $\rightarrow$ the efficiency of public governance".

\section{RESEARCH METHODS}

Assessment of the interconnection between the institutional environment and oil production, oil rents, the level of corruption and the efficiency of public governance could be conducted based on the dynamic models and using the Generalised Method of Moments (GMM), proposed by Arellano-Bond (1991):

$$
\Delta \mathrm{Y}_{\mathrm{i}, \mathrm{t}}=\alpha_{\mathrm{i}} \Delta \mathrm{Y}_{\mathrm{i}, \mathrm{t}-1}+\beta_{\mathrm{i}} \Delta \mathrm{X}_{\mathrm{i}, \mathrm{t}}+\Delta \varepsilon_{\mathrm{i}, \mathrm{t}}
$$

where $Y_{i t}-$ the dependent variable, $X_{i, t}-$ vector of explanatory variables, $\alpha, \beta$, and $\lambda-$ parameters to be estimated; $\varepsilon_{i t}-$ statistical error; $\Delta-$ the first difference sign; and $\mathrm{i}$ and $\mathrm{t}$ represent country and time, respectively.
Based on the above, the empirical model (3-5) can be represented as:

$\Delta \mathrm{OP}_{\mathrm{i}, \mathrm{t}}=\alpha_{1} \Delta \mathrm{OP}_{\mathrm{i}, \mathrm{t}-1}+\zeta_{1} \Delta$ Corruption $_{\mathrm{i}, \mathrm{t}}+\zeta_{2 \mathrm{i}} \Delta \mathrm{Z}_{\mathrm{it}}+\Delta \varepsilon_{\mathrm{i}, \mathrm{t}}$

$\Delta$ Corruption $_{\mathrm{i}, \mathrm{t}}=\alpha_{2} \Delta$ Corruption $_{\mathrm{i}, \mathrm{t}-1}+\zeta_{3} \Delta \mathrm{OP}_{\mathrm{i}, \mathrm{t}}+$ $+\zeta_{4} \Delta \mathrm{Z}_{\mathrm{i}, \mathrm{t}}+\Delta \varepsilon_{\mathrm{i}, \mathrm{t}}$

$\Delta \mathrm{Z}_{\mathrm{i}, \mathrm{t}}=\alpha_{3} \Delta \mathrm{Z}_{\mathrm{i}, \mathrm{t}-1}+\zeta_{5} \Delta$ Corruption $_{\mathrm{i}, \mathrm{t}}+\zeta_{6} \Delta \mathrm{OP}_{\mathrm{i}, \mathrm{t}}+\Delta \varepsilon_{\mathrm{i}, \mathrm{t}}$

where $\alpha_{1} \ldots \alpha_{3}, \zeta_{1}-\zeta_{6}-$ model constants; $\mathrm{OP}_{\mathrm{i}, \mathrm{t}}-$ indicators of oil industry functioning $\left(\mathrm{OP}_{1}-\right.$ the volume of oil production; $\mathrm{OP}_{2}-$ the volume of rent payments for oil), $\mathrm{Z}_{\mathrm{i}, \mathrm{t}}-$ World Governance indicators which represent the quality of governance; Corruption $_{\text {it }}-$ the Corruption Perceptions Index according to Transparency International; $\varepsilon_{i t}-$ statistical error; $\Delta-$ the first difference sign; and i and $t$ represent country and time, respectively.

It should be noted that the system of world indicators has already been used (Huque et al., 2018; Chou et al., 2018; Sadaf et al., 2018; Awan et al., 2018; Cheng et al., 2017; Nurudeen et al., 2015; Donwa et al., 2015; Kasztelnik et al., 2019) for measuring public administration quality as an information base for evaluating institutional factors (The Worldwide Governance Indicators (WGI)). It should be noted that these indicators have been calculated for 200 countries since 1996 using more than 30 databases, includ- 
ing survey results. Therefore, this sample is representative of both time and country surveys. According to the officially announced methodology, this metric system contains six aggregating indicators, namely, voting rights and accountability; political stability; the effectiveness of the functioning government; the quality of the government's regulatory policy; the rule of law; and the control of corruption.

Accordingly, the Zi,t indicator in the article is evaluated based on several determinants of the institutional environment, namely, the opinions of the population during the formation of political institutions, political stability, the effectiveness of the government, and the level of adherence to the rule of law in the country. The information base of the study was data from 21 countries for the years 2000-2018.

\section{RESEARCH RESULTS}

According to official reports (Kaufmann et al., 2010), countries with high and higher than average incomes rank higher in terms of voting power and accountability. It should be noted that in 2004-2009, there was a positive trend in the growth of the right to vote and accountability. After 2009, the value of this indicator began to decline. The sharp changes in the dynamics of this indicator relate to the existing political and economic conflicts. The dynamics of changing the indicator of voting power and accountability are presented in Fig. 5.

The results of the analysis into the dynamics of the indicator change - the quality of the government's regulatory policy - landed Ukraine in the last position. In terms of this indicator, the position of Ukraine began to decline rapidly after 2004, as with the previous indicator. As of 2004, Ukraine had 39.41 points, and in 2015, it had 29.33 points. It should be noted, that after 2005, the quality of the regulatory policy of the Ukrainian government began to improve, which is confirmed by the growth of the indicator of the quality of the government's regulatory policy in 2018 to 44.23 points.

According to Fig. 6, the lowest positions among the analysed countries during the analysed period of

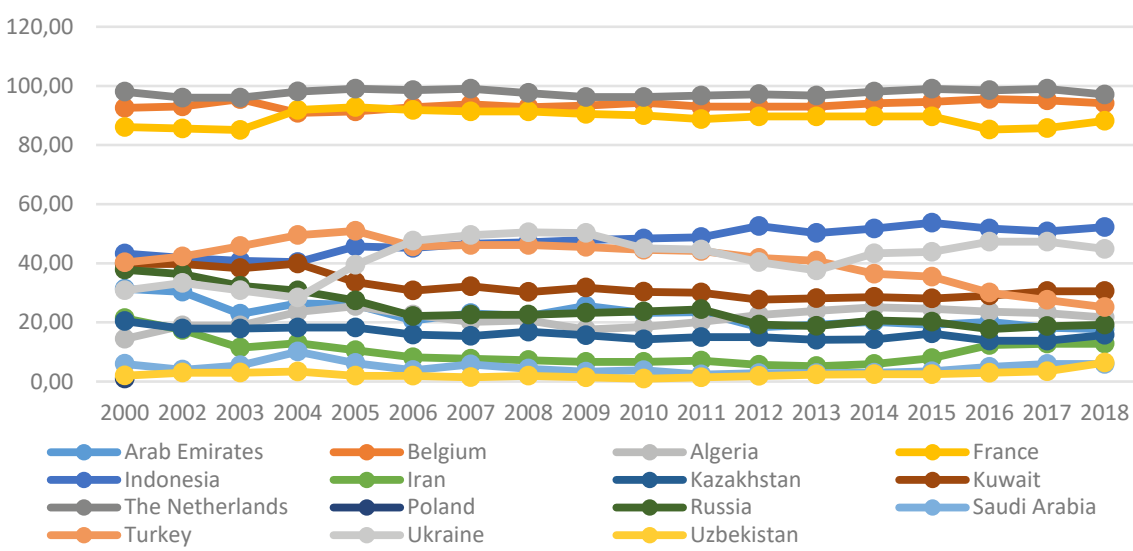

Fig. 5. Dynamics of indicator change: voting rights and accountability in 2000-2018 Source: elaborated by the authors based on (Bilan et al., 2019c).

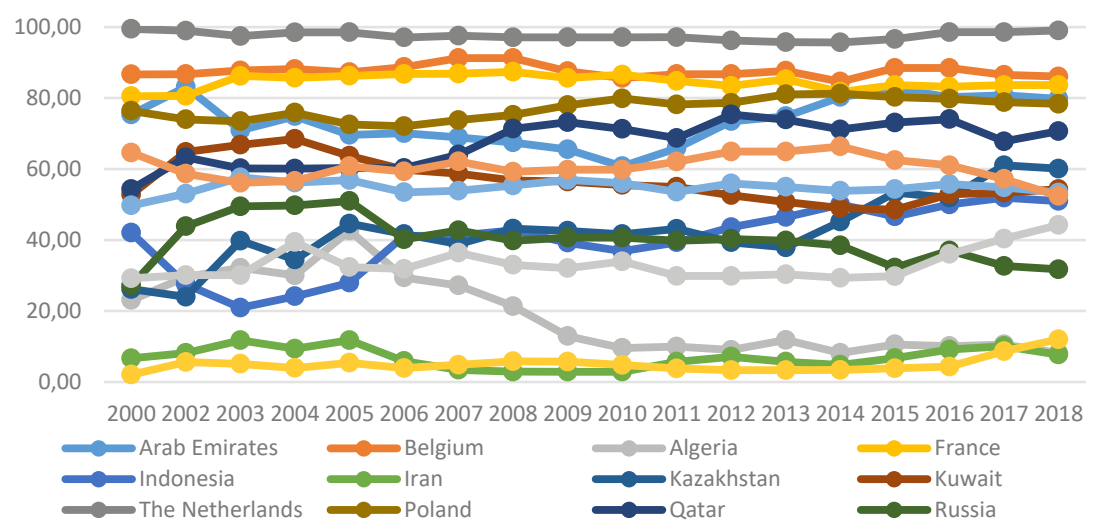

Fig. 6. Dynamics the indicator of the quality of the government's regulatory policy in 2000-2018 Source: elaborated by the authors based on World Governance Indicators. 
2000-2018 were held by Iran and Uzbekistan (Kaufmann et al., 2010). As with the previous indicator (voting rights and accountability), the highest positions was held by the Netherlands. It should be noted that in terms of corruption control, Ukraine also ranked last among the analysed countries. As with the previous indicators, the dynamics of the decline was observed after 2005, and the lowest value was found in 2013, which was 11.37 points. In 2016 and 2017, the value of this indicator increased almost twice and amounted to 21.5 and 22.12 points, respectively.

The downward trend is also observed in Kuwait, Turkey, Algeria and Iran. As of 2002, the indicator of the control of corruption for Kuwait was 82.83 points, and in 2017, it was almost twice lower at 44.71 points; in Iran, in 2002, it was 50.0 points, while in 2017, it was 22.12 points. Uzbekistan, Kazakhstan and Russia have similar points to Ukraine for this indicator.

According to the results of the analysis (Fig. 8), Kazakhstan was the leader in all indicators of government efficiency in 2016. Ukraine was ahead of Russia and Uzbekistan in the indicators of the rule of law and the control of corruption.

Russia was in the lead in terms of voting rights and accountability; the efficiency of the functioning government; and the quality of the government's regulatory policy.

In 2016, Uzbekistan achieved better results than Ukraine and Russia in terms of political stability.

Based on the comparison of the values for government performance indicators by Ukraine, Russia, Kazakhstan and Uzbekistan, Kazakhstan ranked first in almost all parameters in 2017. Ukraine had a bet- ter-quality regulatory policy, the rule of law and anti-corruption controls than Russia and Uzbekistan. Meanwhile, Russia had almost the same position with Kazakhstan in terms of the efficiency of the functioning government (Fig. 9).

In 2018, Kazakhstan was also the leader in all indicators. Russia was ahead of Ukraine and Uzbekistan in three indicators: the control of corruption; voting rights and accountability; and the efficiency of the functioning government.

Compared to 2016 and 2017, Ukraine's position in terms of the indicator of the control of corruption dropped in 2018; however, the quality of the government's regulatory policy received a better ranking. Fig. 10 presents a graphical interpretation of the effectiveness of the state governance in Ukraine, Russia, Kazakhstan and Uzbekistan for 2018 in terms of main components.

Summarising the results of the analysis into Ukraine's position in terms of indicators of the effectiveness of the government, a conclusion can be drawn that in 2016-2018, only three indicators increased among the six, namely, voting rights and accountability, the effectiveness of the functioning government, and the quality of the government's regulatory policy.

In 2018, there was a slight decrease in indicators of political stability and the rule of law.

At the same time, there was a significant decrease in the indicator of the control of corruption. Fig. 11 presents the dynamics of change in the performance indicators of the state governance in Ukraine for 2016-2018 in terms of major components.

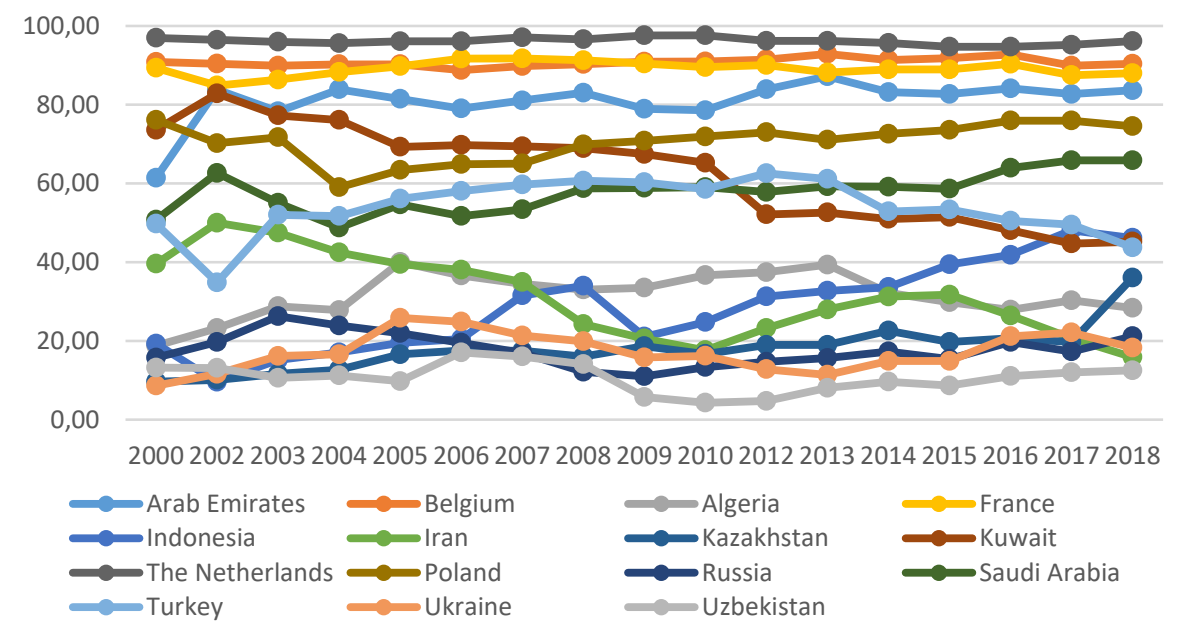

Fig. 7. Dynamics of the indicator or the control of corruption in 2000-2018

Source: elaborated by the authors based on World Governance Indicators. 


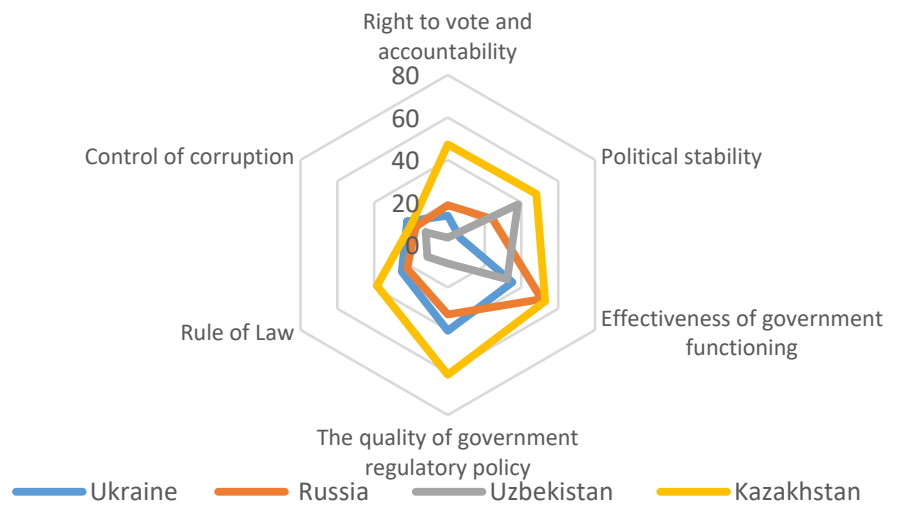

Fig. 8. Public Governance Effectiveness in Ukraine, Russia, Kazakhstan and Uzbekistan in 2016 Source: elaborated by the authors base on World Governance Indicators.

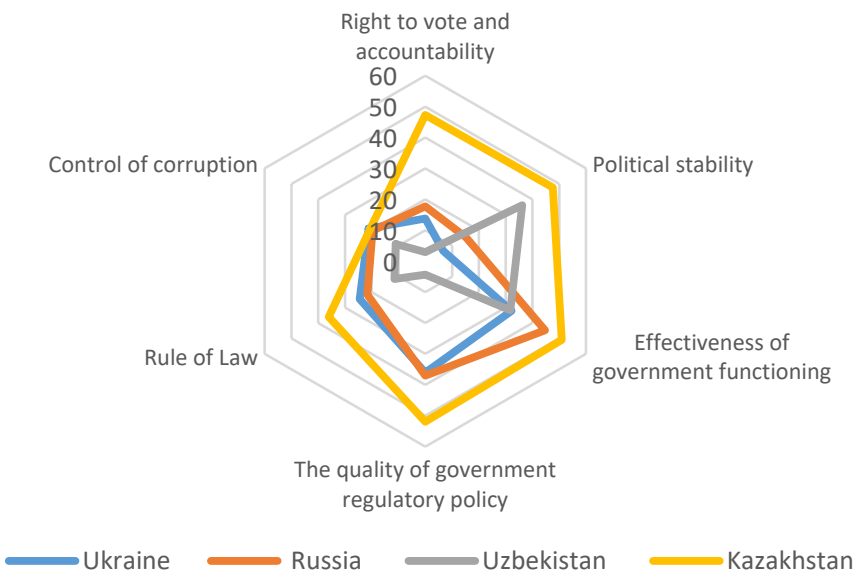

Fig. 9. Efficiency of government in Ukraine, Russia, Kazakhstan and Uzbekistan in 2017 Source: elaborated by the authors base on World Governance Indicators.

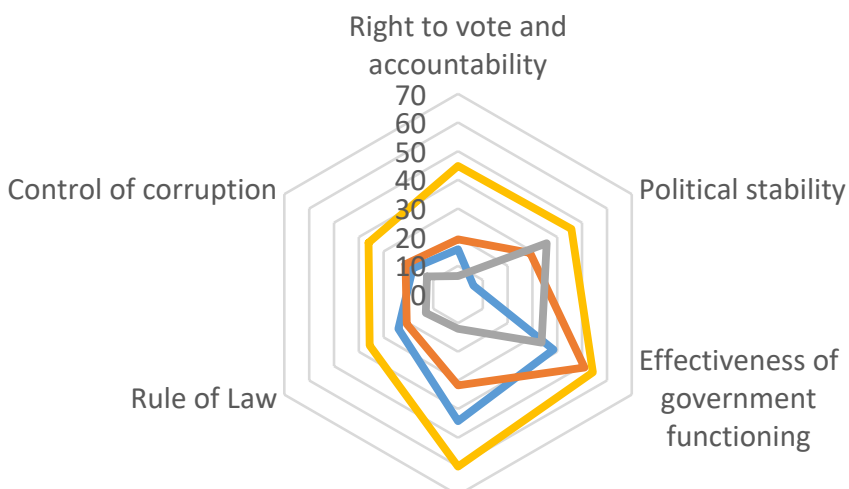

The quality of government regulatory policy

Ukraine Russia Uzbekistan $=$ Kazakhstan

Fig. 10. Public Governance Effectiveness in Ukraine, Russia, Kazakhstan and Uzbekistan in 2018 Source: elaborated by the authors base on World Governance Indicators. 


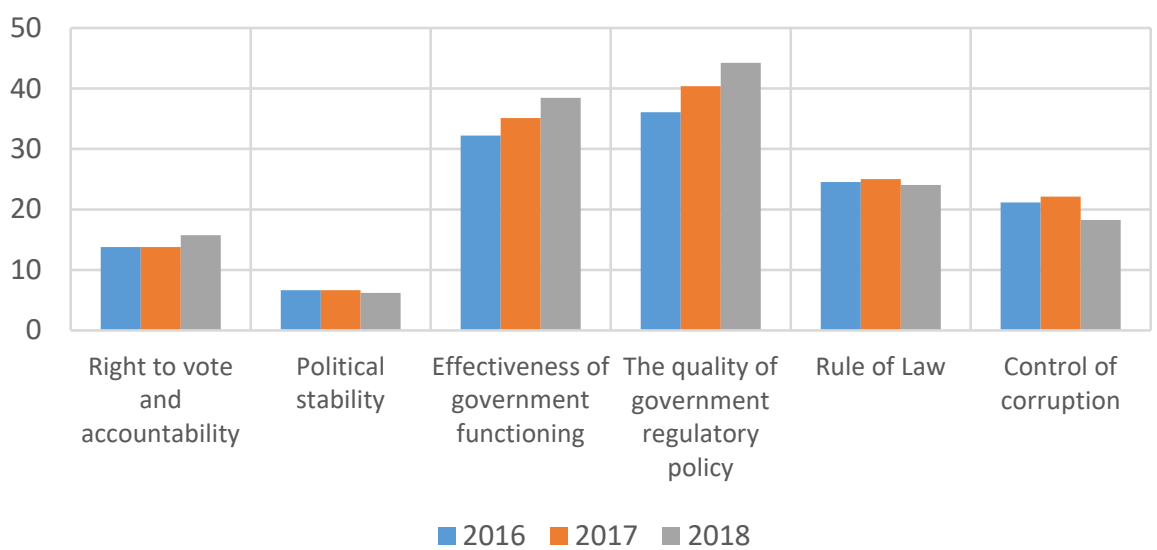

Fig. 11. Dynamics of indicators for the effectiveness of public governance in Ukraine in 2016-2018 by key components Source: elaborated by the authors base on World Governance Indicators.

The trends represented in Fig. 11 show the tendency for the growth basically in all determinants. A significant increase characterises the effectiveness of the functioning government and the quality of the government's regulatory policy in comparison with political stability.

\section{DISCUSSION OF THE RESULTS}

The authors of the article calculated the parameters related to the model of interdependence between indicators showing the national development of the institutional environment and the oil production industry (Table 1). The information base consisted of data from 21 countries for 2000-2018. The correlations between the variables in the empirical model (3) are presented in Table 1.

The calculations confirmed that at the present stage of development of the national economy, oil rents are associated with corruption and are a direct threat to the stability of state institutions. Based on Table 1, there is a high correlation between PS and GE, which means that the inclusion of two indicators of the state government performance in the model (3-4) would create a multicollinearity problem. Therefore, the assessment of the impact made by the institutional environment on the functioning of the

Tab. 1. Correlations between variables $\mathrm{OP}_{1}, \mathrm{OP}_{2}, \mathrm{ViA}, \mathrm{PS}, \mathrm{GE}, \mathrm{RL}$

\begin{tabular}{|c|c|c|c|c|c|c|}
\hline & $\mathrm{OP}_{1}$ & $\mathrm{OP}_{2}$ & ViA & PS & GE & $\mathbf{R L}$ \\
\hline $\mathrm{OP}_{1}$ & 1.0000 & $\begin{array}{r}0.4561 \\
(0.0001)\end{array}$ & $\begin{array}{r}-0.1593 \\
(0.5147)\end{array}$ & $\begin{array}{r}0.3484 \\
(0.0000)\end{array}$ & $\begin{array}{r}-0.3762 \\
(0.1125)\end{array}$ & $\begin{array}{r}0.0127 \\
(0.9588)\end{array}$ \\
\hline $\mathrm{OP}_{2}$ & $\begin{array}{r}0.4561 \\
(0.0001)\end{array}$ & 1.0000 & $\begin{array}{r}-0.2110 \\
(0.3859)\end{array}$ & $\begin{array}{r}0.3476 \\
(0.0002)\end{array}$ & $\begin{array}{r}-0.4559 \\
(0.0498)\end{array}$ & $\begin{array}{r}-0.3060 \\
(0.2026)\end{array}$ \\
\hline ViA & $\begin{array}{r}-0.1593 \\
(0.5147)\end{array}$ & $\begin{array}{r}-0.2110 \\
(0.3859)\end{array}$ & 1.0000 & $\begin{array}{r}-0.1464 \\
(0.5497)\end{array}$ & $\begin{array}{r}-0.0138 \\
(0.9552)\end{array}$ & $\begin{array}{r}0.4578 \\
(0.0487)\end{array}$ \\
\hline PS & $\begin{array}{r}0.3484 \\
(0.0000)\end{array}$ & $\begin{array}{r}0.3476 \\
(0.0002)\end{array}$ & $\begin{array}{r}-0.1464 \\
(0.5497)\end{array}$ & 1.0000 & $\begin{array}{r}-0.644 \\
(0.0029)\end{array}$ & $\begin{array}{r}-0.1187 \\
(0.6285)\end{array}$ \\
\hline GE & $\begin{array}{r}-0.3762 \\
(0.1125)\end{array}$ & $\begin{array}{r}-0.4559 \\
(0.0498)\end{array}$ & $\begin{array}{r}-0.0138 \\
(0.9552)\end{array}$ & $\begin{array}{r}-0.644 \\
(0.0029)\end{array}$ & 1.0000 & $\begin{array}{r}0.3326 \\
(0.1641)\end{array}$ \\
\hline RL & $\begin{array}{r}0.0127 \\
(0.9588)\end{array}$ & $\begin{array}{r}-0.3060 \\
(0.2026)\end{array}$ & $\begin{array}{r}0.4578 \\
(0.0487)\end{array}$ & $\begin{array}{c}-0.1187 \\
(0.6285)\end{array}$ & $\begin{array}{r}0.3326 \\
(0.1641)\end{array}$ & 1.0000 \\
\hline
\end{tabular}

$\mathrm{OP}_{1}$ - the volume of oil production; $\mathrm{OP}_{2}$ - the volume of rent payments for oil; ViA - indicator of the opinion of the population during the formation of political institutions; PS - the political stability indicator; GE - governance performance indicator; $\triangle \mathrm{RL}$ - the rule of law indicator; Corruption - the corruption perception index; in () - the level of significance. 
Tab. 2. Results of the study into the impact of the institutional environment on the functioning of the national oil-production industry

\begin{tabular}{|c|c|c|c|c|c|c|c|c|c|c|c|c|c|c|}
\hline & \multicolumn{14}{|c|}{ MODEL SPECIFICATION } \\
\hline & \multirow{2}{*}{\multicolumn{2}{|c|}{$\begin{array}{c}\Delta \text { CORRUPTION } \\
\text { STAT. (PROB.) }\end{array}$}} & \multirow{2}{*}{\multicolumn{2}{|c|}{$\frac{\Delta O P_{1}}{\text { StAT. (PROB.) }}$}} & \multirow{2}{*}{\multicolumn{2}{|c|}{$\frac{\Delta O P_{2}}{\text { STAT. (PROB.) }}$}} & \multicolumn{2}{|c|}{$\Delta V I A$} & \multicolumn{2}{|c|}{$\Delta \mathrm{PS}$} & \multicolumn{2}{|c|}{$\Delta \mathrm{GE}$} & \multicolumn{2}{|c|}{$\Delta R L$} \\
\hline & & & & & & & StAT. & PROB. & StAT. & PROB. & Stat. & PROB. & StAT. & PRoB. \\
\hline Corruption & $\begin{array}{r}0.12 \\
(0.00)\end{array}$ & $\begin{array}{r}0.11 \\
(0.00)\end{array}$ & $\begin{array}{l}-0.16 \\
(0.00)\end{array}$ & $\begin{array}{l}-0.09 \\
(0.00)\end{array}$ & -0.04 & 0.00 & 0.04 & 0.00 & -0.03 & 0.355 & 0.03 & 0.00 & 0.17 & 0.00 \\
\hline $\mathrm{OP}_{1}$ & $\begin{array}{r}1.47 \\
(0.16)\end{array}$ & $\begin{array}{r}1.34 \\
(0.08)\end{array}$ & $\begin{array}{l}0.521 \\
(0.00)\end{array}$ & $\begin{array}{l}0.687 \\
(0.00)\end{array}$ & - & - & -0.10 & 0.14 & 0.08 & 0.00 & -0.06 & 0.20 & 0.06 & 0.15 \\
\hline $\mathrm{OP}_{2}$ & $\begin{array}{l}-0.54 \\
(0.00) \\
\end{array}$ & $\begin{array}{l}-0.52 \\
(0.00) \\
\end{array}$ & - & - & $\begin{array}{l}0.490 \\
(0.00) \\
\end{array}$ & $\begin{array}{l}0.831 \\
(0.00) \\
\end{array}$ & -0.98 & 0.00 & 0.34 & 0.72 & 0.19 & 0.37 & -0.13 & 0.46 \\
\hline ViA & $\begin{array}{r}0.28 \\
(0.00)\end{array}$ & $\begin{array}{l}0.34 \\
(0.0)\end{array}$ & $\begin{array}{r}0.30 \\
(0.41)\end{array}$ & $\begin{array}{r}0.27 \\
(0.44)\end{array}$ & $\begin{array}{r}0.49 \\
(0.03)\end{array}$ & $\begin{array}{r}0.64 \\
(0.52)\end{array}$ & 0.09 & 0.012 & - & - & - & - & - & - \\
\hline PS & $\begin{array}{r}1.25 \\
(0.23)\end{array}$ & - & $\begin{array}{r}0.23 \\
(0.06)\end{array}$ & - & $\begin{array}{r}0.13 \\
(0.08)\end{array}$ & - & - & - & 0.208 & 0.00 & - & - & - & - \\
\hline $\mathrm{GE}$ & - & $\begin{array}{r}0.18 \\
(0.00)\end{array}$ & - & $\begin{array}{r}0.51 \\
(0.18)\end{array}$ & - & $\begin{array}{r}0.42 \\
(0.06)\end{array}$ & - & - & - & - & 0.308 & 0.00 & - & - \\
\hline $\mathrm{RL}$ & $\begin{array}{r}0.48 \\
(0.92)\end{array}$ & $\begin{array}{r}0.49 \\
(0.87)\end{array}$ & $\begin{array}{r}0.32 \\
(0.53)\end{array}$ & $\begin{array}{r}0.28 \\
(0.48)\end{array}$ & $\begin{array}{l}-0.15 \\
(0.63)\end{array}$ & $\begin{array}{l}-0.10 \\
(0.84)\end{array}$ & - & - & - & - & - & - & 0.07 & 0.05 \\
\hline$A R(2)$ & (0.209) & $(0.312)$ & $(0.311)$ & $(0.291)$ & $(0.243)$ & $(0.218)$ & & (0.149) & & (0.178) & & $(0.269)$ & & (0.117) \\
\hline $\begin{array}{l}\text { Sargan's } \\
\text { OIR stat. }\end{array}$ & $(0.967)$ & $(0.341)$ & $(0.237)$ & $(0.414)$ & $(0.220)$ & $(0.145)$ & & $(0.136)$ & & (0.180) & & $(0.213)$ & & $(0.385)$ \\
\hline $\begin{array}{l}\text { Hansen's } \\
\text { OIR stat. }\end{array}$ & $(0.782)$ & $(0.492)$ & $(0.623)$ & $(0.625)$ & $(0.618)$ & $(0.713)$ & & $(0.487)$ & & $(1.00)$ & & $(0.503)$ & & $(0.578)$ \\
\hline
\end{tabular}

AR(2) is the Second-order autocorrelation of residuals; Sargan's OIR stat. and Hansen`s OIR stat. - Sargan and Hansen OIR tests; OIR is the Over-identifying Restrictions Test.

national oil-production industry was made based on the PS and GE indicators separately.

Table 2 represents the results of the study into the impact of the institutional environment on the functioning of the national oil-production industry.

The calculations confirmed (Table 2) that at the current stage of the development of the national economy, oil rents are associated with corruption and are a direct threat to the stability of public institutions. An increase in rents for oil by one point of standard deviation increases the level of corruption by 0.54 points of standard deviation. At the same time, an increase in the level of corruption is associated with an increase in the level of rent payments and occurs only when the quality of democratic institutions is below the threshold level (0.54 standard deviation points). However, the current level of efficiency of public administration does not significantly impact on the national oil-production indus- try. Of all indicators, only the level of political stability had a statistically significant impact (at 1\%) on oil production. Improving political stability by 1.0 -point standard deviation will increase oil production by 0.08 standard deviation.

\section{CONCLUSIONS}

Sustainable development of the oil-production industry should be understood as a process of the capacity building considering the interference of the effects of cross-sectoral interaction. The system of measures for ensuring the sustainable development of oil production has to be aimed at preventing the adverse economic, institutional, social and economic effects of the functioning industry. The analysis made it possible to determine that the development of efficient state institutions will contribute to the development of the oil production industry, will reduce the 
country's energy dependence and strengthen the stability of the national economy.

To assess the impact of the functioning institutional environment on the development of the national oil industry, the hypothesis was formulated regarding the changes in the institutional environment and their relationships being in the form of the chain "oil production and oil rents $\rightarrow$ the level of corruption $\rightarrow$ the efficiency of public administration". To confirm the hypothesis, a scientific and methodological approach was developed, which involved building a system of dynamic models and using a generalised method of moments.

The substantiation of the influence of the institutional environment on the functioning of the national oil production industry showed that the increase in oil rents by one point of standard deviation increased the level of corruption by 0.54 points. The increase in the level of corruption is caused by the increase in the shadow in the oil production industry and occurs when the quality of democratic institutions is below the threshold level. An increase in the level of political stability by one point of standard deviation causes an increase in oil production by 0.08 points of standard deviation.

A proposed theoretical approach for the assessment of the institutional impact on the oil production industry will form the background for the formation of a stimulating institutional environment with the possibility of using appropriate tools for different hierarchical levels of the national economy, creating efficient state policy for the oil-production industry, and developing effective state institutions. It will promote the development of the oil industry and reduce the country's energy dependence and strengthen the resilience of the national economy.

\section{ACKNOWLEDGEMENTS}

This research was funded by the grant from the Ministry of Education and Science of Ukraine (Nos. g/r 10117U003932 and 0119U101860).

\section{LITERATURE}

Abaas, M. S. M., Chygryn, O., Kubatko, O., \& Pimonenko, T. (2018). Social and economic drivers of national economic development: The case of OPEC countries. Problems and Perspectives in Management, 16(4), 155-168. doi: 10.21511/ppm.16(4).2018.14
Augbaka, M., Awujola, A., \& Shcherbyna, T. (2019). Economic Development, Foreign Aid and Poverty Reduction: Paradigm in Nigeria. SocioEconomic Challenges, 3(4), 5-12. doi: 10.21272/sec.3(4).5-12.2019

Awan, R. U., Akhtar, T., Rahim, S., Sher, F., \& Cheema, A. R. (2018). Governance, corruption and economic growth: a panel data analysis of selected SAARC countries. Pakistan Economic and Social Review, 56(1), 1-20. Retrieved from http://pu.edu.pk/ images/journal/pesr/PDF-FILES/1-v56_1_18.pdf

Bhowmik, D. (2019). Decoupling CO2 Emissions in Nordic countries: Panel Data Analysis. SocioEconomic Challenges, 3(2), 15-30. doi: 10.21272/sec.3(2).15-30.2019

Bilan, Y., Lyeonov, S., Lyulyov, O., \& Pimonenko, T. (2019a). Brand management and macroeconomic stability of the country. [Zarządzanie marką i stabilność makroekonomiczna kraju]. Polish Journal of Management Studies, 19(2), 61-74.

Bilan, Y., Lyeonov, S., Stoyanets, N., \& Vysochyna, A. (2018a). The impact of environmental determinants of sustainable agriculture on country food security. International Journal of Environmental Technology and Management, 21(5-6), 289-305.

Bilan, Y., Raišienè, A. G., Vasilyeva, T., Lyulyov, O., \& Pimonenko, T. (2019b). Public Governance efficiency and macroeconomic stability: examining convergence of social and political determinants. Public Policy and Administration, 18(2), 241-255. doi: 10.13165/VPA19-18-2-05

Bilan, Y., Vasilyeva, T., Lyeonov, S., \& Bagmet, K. (2019c). Institutional complementarity for social and economic development. Business: Theory and Practice, 20, 103-115. doi: 10.3846/btp.2019.10

Boiko, V., Kwilinski, A., Misiuk, M., \& Boiko, L. (2019). Competitive advantages of wholesale markets of agricultural products as a type of entrepreneurial activity: the experience of Ukraine and Poland. Economic Annals-XXI, 175(1-2), 68-72. doi: 10.21003/ea.V17512

Brychko, M., Bilan, Y., Buriak, A., \& Vasilyeva, T. (2019). Financial, business and trust cycles: The issues of synchronization [Ciklusi financiranja, poslovanja i povjerenja: pitanja za sinkronizaciju]. Zbornik $R a$ dova Ekonomskog Fakultet Au Rijeci, 37(1), 113-138. doi: 10.18045/zbefri.2019.1.113

Cebula, J., Chygryn, O., Chayen, S. V., \& Pimonenko, T. (2018). Biogas as an alternative energy source in Ukraine and Israel: Current issues and benefits. International Journal of Environmental Technology and Management, 21(5-6), 421-438. doi: 10.1504/ IJETM.2018.100592

Cheng, G., \& Hongbao, Q. (2017). Fiscal Policy, Corruption and Economic Growth: A Theoretical Analysis and Empirical Investigation. Comparative Economic \& Social Systems, 7(4).

Chou, B., \& Huque, A. S. (2018). Governance for Inclusive Development in South and East Asia: A Comparison of India and China. Inclusive Governance in South Asia, 251-273. doi: 10.1007/978-3-319-60904-1_14

Chygryn, O., Pimonenko, T., Luylyov, O., \& Goncharova, A. (2018). Green bonds like the incentive instrument for cleaner production at the government and corpo- 
rate levels: Experience from EU to Ukraine. Journal of Environmental Management and Tourism, 9(7), 1443-1456. doi: 10.14505//jemt.v9.7(31).09

Czyżewski, B., Matuszczak, A., \& Miśkiewicz, R. (2019). Public goods versus the farm price-cost squeeze: shaping the sustainability of the EU's common agricultural policy. Technological and Economic Development of Economy, 25(1), 82-102. doi: 10.3846/ tede.2019.7449

Donwa, P. A., Mgbame, C. O., \& Julius, O. M. (2015). Corruption in the oil and gas industry: Implication for economic growth. Nigerian Chapter of Arabian Journal of Business and Management Review, 62(2468), 1-16.

Dźwigoł, H., \& Wolniak, R. (2018). Controlling w procesie zarządzania chemicznym przedsiębiorstwem produkcyjnym [Controlling in the management process of a chemical industry production company]. Przemysł Chemiczny, 97(7), 1114-1116. doi: 10.15199/62.2018.7.15

Dzwigol, H., Dzwigol-Barosz, M., Miskiewicz, R., \& Kwilinski, A. (2020). Manager Competency Assessment Model in the Conditions of Industry 4.0. Entrepreneurship and Sustainability Issues, 7(4), 2630-2644. doi: 10.9770/jesi.2020.7.4(5)

Grenäãkovã, A., Bilan, Y., Samusevych, Y., \& Vysochyna, A. (2019). Drivers and inhibitors of entrepreneurship development in Central and Eastern European countries. Paper presented at the Proceedings of the 33rd International Business Information Management Association Conference, IBIMA 2019: Education Excellence and Innovation Management through Vision 2020, 2536-2547.

Gudanowska, A. E. (2017). A map of current research trends within technology management in the light of selected literature. Management and Production Engineering Review, 8(1), 78-88.

Halicka, K. (2017). Main concepts of technology analysis in the light of the literature on the subject. Procedia Engineering, 182, 291-298.

Haque, E. (2019). Balancing Freedom of the Press and Reasonable Restrictions in Bangladesh: An Appraisal. Business Ethics and Leadership, 3(1), 80-100. doi: 10.21272/bel.3(1).80-100.2019

Hasan, S., \& Dutta, P. (2019). Coverage of Environmental Issues in Local Dailies of Chattogram Centering World Environment Day. SocioEconomic Challenges, 3(4), 63-71. doi: 10.21272/sec.3(4).63-71.2019

He, S. (2019). The Impact of Trade on Environmental Quality: A Business Ethics Perspective and Evidence from China. Business Ethics and Leadership, 3(4), 43-48. doi: 10.21272/bel.3(4).43-48.2019

Huque, A. S., \& Jongruck, P. (2018). The challenge of assessing governance in Asian states: Hong Kong in the Worldwide Governance Indicators ranking. Asian Journal of Political Science, 26(2), 276-291. doi: 10.1080/02185377.2018.1485587

Kasztelnik, K. \& Gaines, V. W. (2019). Correlational Study: Internal Auditing and Management Control Environment Innovation within Public Sector in the United States. Financial Markets, Institutions and Risks, 3(4), 5-15. doi: 10.21272/fmir.3(4). 5-15.2019
Kaufmann, D., Kraay, A. \& Mastruzzi, M. (2010). The Worldwide Governance Indicators: A Summary of Methodology, Data and Analytical Issues. World Bank Policy Research Working Paper, 5430.

Kozmenko, O. V., \& Pakhnenko, O. M. (2011). Financial methods of catastrophe risks management. Actual Problems of Economics, 118(4), 217-223.

Kuzior, A., Kwilinski, A., \& Tkachenko, V. (2019). Sustainable development of organizations based on the combinatorial model of artificial intelligence. Entrepreneurship and Sustainability, 7(2), 1353-1376. doi: 10.9770/jesi.2019.7.2(39)

Kwilinski, A. (2018). Mechanism of formation of industrial enterprise development strategy in the information economy. Virtual Economics, 1(1), 7-25. doi: 10.34021/ve.2018.01.01(1)

Levchenko, V., Kobzieva, T., Boiko, A., \& Shlapko, T. (2018). Innovations in Assessing the Efficiency of the Instruments for the National Economy De-Shadowing: the State Management Aspect. Marketing and Management of Innovations, 4, 361-371. doi: 10.21272/ mmi.2018.4-31

Lyeonov, S., Pimonenko, T., Bilan, Y., Štreimikiene, D., \& Mentel, G. (2019). Assessment of green investments' impact on sustainable development: Linking gross domestic product per capita, greenhouse gas emissions and renewable energy. Energies, 12(20). doi: $10.3390 /$ en 12203891

Lyulyov, O., Bilan, Y., Vasilyeva, T., \& Pimonenko, T. (2019c). EU vector of Ukraine development: Linking between macroeconomic stability and social progress. International Journal of Business and Society, 20(2), 433-450.

Lyulyov, O., Pimonenko, T., Stoyanets, N., \& Letunovska, N. (2019). Sustainable development of agricultural sector: Democratic profile impact among developing countries. Research in World Economy, 10(4), 97-105. doi: 10.5430/rwe.v10n4p97

Marcel, D. T. Am. (2019). Impact of the Foreign Direct Investment on Economic growth on the Re-public of Benin. Financial Markets, Institutions and Risks, 3(2), 69-78. doi: 10.21272/fmir.3(2).69-78.2019

Mentel, G., Vasilyeva, T., Samusevych, Y., \& Pryymenko, S. (2018). Regional differentiation of electricity prices: Social-equitable approach. International Journal of Environmental Technology and Management, 21(56), 354-372.

Miśkiewicz, R. (2018). The importance of knowledge transfer on the energy market. Polityka Energetyczna, 21(2), 49-62. doi: $10.24425 \% 2 \mathrm{~F} 122774$

Miśkiewicz, R., \& Wolniak, R. (2020). Practical Application of the Industry 4.0 Concept in a Steel Company. Sustainability, 12(14), 5776. doi: 10.3390/su12145776

Mlaabdal, S., \& Chygryn, O. (2017). Analysis of the features of the world energy market development. Bulletin of Sumy State University. Economy Series, 4, 140-145.

Naser, N. (2019). The Interaction between Profitability and Macroeconomic Factors for Future Examinations of European Banks Soundness - Theoretical Study. Financial Markets, Institutions and Risks, 3(3), 6397. doi: 10.21272/fmir.3(3). 63-97.2019 
Nurudeen, A., Abd Karim, M. Z., \& Aziz, M. I. (2015). Corruption, political instability and economic development in the Economic Community of West African States (ECOWAS): is there a causal relationship? Contemporary Economics, 9(1), 45-60.

Pimonenko, T., Chygryn, O., \& Luylov, O. (2018). Green Entrepreneurship as an Integral Part of the National Economy Convergence. National Security \& Innovation Activities: Methodology, Policy and Practice. Bielsko-Biala, Poland: University of Bielsko-Biala.

Pleines, H., \& Wöstheinrich, R. (2016). The InternationalDomestic Nexus in Anti-corruption Policy Making: The Case of Caspian Oil and Gas States. Europe-Asia Studies, 68(2), 291-311. doi: 10.1080/09668136.2015 .1126232

Sadaf, R., Oláh, J., Popp, J., \& Máté, D. (2018). An investigation of the influence of the worldwide governance and competitiveness on accounting fraud cases: A cross-country perspective. Sustainability, 10(3), 588. doi:10.3390/su10030588

Siderska, J., \& Jadaa K. S. (2018). Cloud manufacturing: a service-oriented manufacturing paradigm. A review paper. Engineering Management in Production and Services, 10(1), 22-31.

Singh, S. N. (2019). Private Investment and Business Opportunities in Ethiopia: A Case Study of Mettu Town in Ethiopia. Business Ethics and Leadership, 3(4), 91104. doi: 10.21272/bel.3(4).91-104.2019

Sokolenko, L. F., Tiutiunyk, I. V., \& Leus, D. V. (2017). Ecological and economic security assessment in the system of regional environmental management: A case study of Ukraine. International Journal of Ecology and Development, 32(3), 27-35.

Szpilko, D. (2017). Tourism Supply Chain - overview of selected literature. Procedia Engineering, 182, 687-693.

Vasilieva, T., Lieonov, S., Makarenko, I., Sirkovska, N. (2017). Sustainability information disclosure as an instrument of marketing communication with stakeholders: markets, social and economic aspects. Marketing and Management of Innovations, 350-357. doi: 10.21272/mmi.2017.4-31

Vasilyeva, T., Kuzmenko, O., Bozhenko, V., \& Kolotilina, O. (2019). Assessment of the dynamics of bifurcation transformations in the economy. Paper presented at the CEUR Workshop Proceedings, 2422, 134-146.

Vasylyeva, T. A., \& Pryymenko, S. A. (2014). Environmental economic assessment of energy resources in the context of Ukraine's energy security. Actual Problems of Economics, 160(1), 252-260.

Wale-Awe, O. I., \& Sulaiman, L. A. (2020). Premium Motor Spirit (PMS) pricing and inflationary dynamics in Nigeria. Forum Scientiae Oeconomia, 8(3), 49-60. doi: 10.23762/FSO_VOL8_NO3_3

Winkowska, J., Szpilko, D., \& Pejić, S. (2019). Smart city concept in the light of the literature review. Engineering Management in Production and Services, 11(2), 70-86.

Yevdokimov, Y., Chygryn, O., Pimonenko, T., \& Lyulyov, O. (2018). Biogas as an alternative energy resource for Ukrainian companies: EU experience. Innovative Marketing, 14(2), 7-15. doi:21511/im.14(2).2018.01 